\section{d ithirror}

\section{HOSPITAL PRACTICE, BRITISH AND FOREIGN.}

Nula autem est alia pro certo noscendi via, nisi quamplurimas et morborum et dissectionum historias, tum aliorum tum proprias collectas habere, et inter se comparare.-MoseaGNI De Sed. et Caus. Morb., lib. iv. Procemium.

\section{MANCHESTER ROYAL INFIRMARY.}

CASE OF EPITHELIOMA OF THE SCROTUM IN A YOUTH. (Under the care of Mr. HeATH.)

For the following arites we are indebted to Mr. John Sheldon Withers, M. R.C.S., late house-surgeon.

W. L- aged eighteen, a block cutter, was admitted to hospital. No tendency to $m$, lignant disease discoverable in his family. Patient had always had robust bealth. No history of injury or irritation. A hout a year before admission the patient noticed a small hard swelling as large as a marble in the right and lower part of his scrotum. It grew rapidly, reaching the size of a hen's egg in less than three months. Four months later (it had spread far in the meantime) the right iuguiual glands began to enlarge and soon afterwards the lert. It did not cause him pain till nive months after its commencem-nt, when a nightly aching began from which he has not since been free. His parents discovered it ouly when far advanced by noticing a peculiarity in his gait.

Condition on admission :--Pain has now made his expression careworn, but for this $h \rightarrow$ wight be taken as the type of a healthy country lar. He is of fair complexion, rosy cheeked, and well nourished. The growth involves the whole of the scrotum; its surface is irregular and nodulated, The nodules are of very variable size, some being no larger than a marble, whilst o hers are as big as a small orange. At its underpart is the mou th of a sinus, which leads to $a$ cavity in the cente of the mass. Here, whilst growth is going on active'y outside, a process of destruction is at work, evidenced by the crinstant discharge of a thin, yellowish, opaque fluid, and occsionally of blood in large quantities. On either aide, the inguinal glands form two arge tuberous masses anherrat to tibe deep structures. In the neighbourhood of the right of thess, one testicle can be felt, the position of the wher cannot be made out. The growth is nowhere tender to the touch, and is of uniform, moderate hardness. Owing to frequent hæmorrhages, he became rapidly worse, ant die $\downarrow$, wasted to the last degree, four months after adm'ssion. Afver death, the testicl. were found to be quite hesalthy. A microscopical examination, made hy several parhologists, among whom were Drs. Dreschfeld and Yoang of Oweas College, proved the tumour to be an epithrlioma. A necro, sy was not allowed.

GENERAL DISPENSARY, NOTTINGHAM.

ANEURISM OF THE INTRA-PERICARDIAL PORTION OF THE AORTA; SUDDEN DEATH FROM RUPTURE; NECROPSY.

FOR the following interesting notes we are indebted to Dr.

\section{Collins,}

On the morning of May 5th, Mrs. B — was suddenly seized with præcor,i $t$ distress whilst talking to some of her friends. She expired in a few minutes and before the arrival of the inedical attendant, though her house was not two hundred yaris distut from the hospital. The history of any previuus iluess was very indefinite. A week before her decease she quarreled witn her husband, and had charged him before the magistrates with assault. Sudden death under such circumstauces assumed an interesting nature, pathologically as well as medico-legally.

Necropsy forty eight hours after death-Apparent age fifty-five; body well usui-hes; no marks of violence. Wheu the thorax was opened the periıardium was found distended with blood. Further exam!nation revealed a very small sacculated aneurism immediately above the right coronary valve. This had ruptureil into the pericardium. The opeuing was small, only sufficient to admit a medium-sized probe. There was no regurgitation through the valves. The aorta was atherumatous, as evidenced by "patchy thickenings and unevenuess on the inuer surface."
Dr. Hayden has pointed out that aortic aneurisms never attain a large size when they are exposed to the maximum of reflux from the aorta. The symptoms and acoustic signs are very indefinite during life. Death was very sudden, and without any warning, as it usually is in such cases.

A coroner's itquest was held, and the question naturally asked was, Did ill-treatment tend to accelerate her death? There was no evidence that it did. She had not lived with her husband the previous week. The grief and anxiety consequent on her domestic infelicity may have contributed materially as a preaisposing cause to the untoward event.

\section{WORCESTER GENERAL INFIRMARY.}

CASE OF COMPLETE SUPPRESSION OF URINE LASTING FIFTY-THREE HOURS, FOLLOWED BY CYSTITIS; RECOVERY.

(Under the care of Mr. HYDE.)

For the following notes we are indebted to Mr. M. B. Shirley, house-surgeon.

John —, aged fifty-eight, came to the casualty-room, at 10 A.M., on May 18th, suffering from stricture of the urethra. He had suffered frum stricture for the last twenty years, and bad had it frequently dilated surgically. Lister's souuds, from No. 9 to No. 12, were passed, aud the patent refusing to stay in the iufirmary was allowed to go home. About 3 P.M. he was brought back, having had a rigor in the street.

On admission he complained of great pain in the lumbar region : temperature $102^{\circ}$; pulse quick and fall. He was put to bed; brandy was given, and warm bottles appiied.

May 19th, 8 P.M. : He has passed to urine since his admission. -20th, 10 A.M. : He has pasted no urine, and is drowsy. Pulse slow and full ; temperature $97^{\circ}$. His tongue brown and furred. The catbeter drew off two ounces of almost pure blood. The bladder was washed out with a solution of carbolic acid, one in 100. He was ordered quarter-grain doses of pilocarpine with half a drachm of sulphate of magnesia every three hours. Loina dry cupped. 8 P.M. : The parsent perspired freely during the day; still no uriue passed. The catheter drew off two cuuces of urine, which deposied pus. The blıdder was washed out. The patient is better. To coninue the medicine. - zilst, 10 A M. : Passed a liltle urine; still perspring profasely. Medicine to be continued.-22nd, 10 A.M. : Has passed twenty ounces of urine during the last twenty-fuur hours, which deposited pus. The bladuer was washed out wich a weak solution of salicylic acid. The medicine stupped23rd: Sixty ounces of urine passed. One outce of jufusion of buchu ordered three times a day. - 27th: The bladder has been washed out twice daily siuce the last note with a solutiou of salicylic acid. The urine is now passed is lange quantities naturally. The cystitis is quite disappeared. The patient expresses himself as quite well.

\section{CITY OF DUBLIN HOSPITAL.} MR. HENRY GRAY CROLY'S CLINIQUE.

The foll wwing cases were recently under Mr. Croly's care, and present mauy points of interest :-

Cellulitis of the Neck.-A man, about thirty-seven, applied on July 3rd with a large tumour of the riuht side of the veck, which had been growing for the past six months. The posterior part of the tum sur was exrremely hard, and a question arose as to whether it might not be a case of medullary sareoma. Mr. Croly used an exploring needle, which permitred a mucs-purulent fluid to excape, aud the man was taken into the theatie and there etherised $f_{t}: r$ further operative measures. A frte incision was made in the lower and ant-rior part of the neck, and the cervical fascia divided on a director, thereby alluning a $f_{1}$ ee discharge of blood and pus. Iu making the necessary iucisions in the reck to divide the rervieal tascia, and thus to relitve tensioa and give exit to the iuf trated fluids, Mr. Croly sketched on the patient's neck befure nperatrny what he called "lives of safety" and "liues of dangtr," and which were described by him in an excellent mono ${ }_{b}$ raph on Cellulitis, published in 1873. The liues of dauger ate those in the direct on of the external jugular vein, whi.h passes from the augle of the jaw downwaids and outwaids acruss the stero-mastoid; and another live corresponing with the carotids in thrir course upwards aud backwardy.

Burns of the Head and Face from a Gas Explosion, caused by Flint and Steel. - This patjent, a labouring man, received 